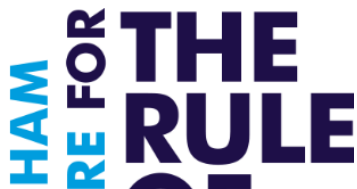

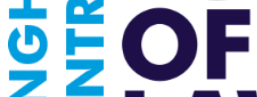 \\ 鯜 LAW
}

\section{THE EU'S RULE OF LAW PROMOTION IN CENTRAL AND EASTERN EUROPE: WHERE AND WHY DOES IT FAIL, AND WHAT CAN BE DONE ABOUT IT?}

\section{MARTIN MENDELSKI}

Bingham Centre for the Rule of Law

Global Rule of Law Exchange Papers

February 2016

www.ruleoflawexchange.org

www.binghamcentre.biicl.org

Opinions expressed in this paper are the authors' alone and do not necessarily reflect those of the Bingham Centre for the Rule of Law or the Global Rule of Law Exchange 


\section{About the author}

Martin Mendelski (mendelsk@uni-trier.de) is a leading academic expert on the rule of law in Central and Eastern Europe (CEE). He received his Ph.D. in political science from the University of Luxembourg and currently lectures at the University of Trier. His dissertation won the THESEUS Promising Award for Research on European Integration. Dr. Mendelski has undertaken empirical research analysing the impact of the EU on the development of the rule of law in CEE, focusing on Romania, Moldova, Poland and the Western Balkans. He has held visiting positions at Harvard University, European University Institute, European Law Academy, Max Planck Institute for the Study of Societies, Max Planck Institute for European Legal History and several universities from CEE. His publications appeared in Constitutional Political Economy, Comparative European Politics, East European Politics, Southeastern Europe, and The Routledge Handbook of East European Politics (forthcoming). His current research focuses on the political economies in CEE, anti-corruption and judicial reform, law \& capitalism and legal pluralism.

\section{About the practice notes}

The Global Rule of Law Exchange ('the Exchange') is a project of the Bingham Centre for the Rule of Law in London supported by law firm Jones Day. The Exchange aims to address key challenges posed by global development and its relationship to the rule of law. It will consider the place of the rule of law in emerging economies, including on issues such as access to justice, administrative justice and corruption. It will also examine the relationship between formal and informal legal systems and the measurement of success in rule of law interventions.

The Exchange also aims to explore and contribute to the evidence-base on the relationship between development and the rule of law. The Exchange launched a call for practice notes in May 2015 to this end. Among other things, these short documents (around 3,000 words) aim to provide new ideas, identify research gaps and discuss what works and what does not in rule of law interventions. The full list of practice notes touch on a wide array of topics, including corruption, access to justice, legal aid, prison systems and international justice mechanisms, and the impact and measurement of rule of law reforms. The list of published practice notes can be accessed online: http://binghamcentre.biicl.org/ruleoflawexchange/research-to-practice

There are two categories of practice notes in the series: 'Comments' capture those that analyse a discrete rule of law issue or theme (e.g. access to justice) and 'Field Notes' tend to be papers that present a new approach or framework to studying rule of law and/or provide new evidence (sometimes drawing on the author's own research). 


\section{'The EU's rule of law promotion in Central and Eastern Europe: Where and why does it fail and what can be done about it?'}

\section{COMMENT}

\section{Introduction}

The European Union (EU) has been hailed as an effective promoter of democracy and the rule of law in Central and Eastern Europe (CEE). ${ }^{1}$ Both official documents/speeches and the Europeanisation literature ${ }^{2}$ claim that the EU has transforming and democratising power and that it brings the rule of law to candidate countries. These optimistic claims conflict with the pre- and post-accession experience of most CEE countries, where the rule of law has not improved significantly and has even deteriorated. The stagnating and even declining trends are reflected in the Bertelsmann rule of law index and the Freedom House judicial framework and independence indicator, both of which show no overall improvement, despite the millions of Euros spent on judicial and anti-corruption reforms. ${ }^{3}$

What impact does the EU have on the rule of law in CEE? This brief policy-oriented paper argues that the EU's impact is uneven: both 'positively-reinforcing' and 'negatively-reinforcing' across four key dimensions of the rule of law (1. formal legality, 2. substantive legality, 3. judicial capacity and 4. judicial impartiality). The paper finds that while, EU-driven judicial reforms increase judicial capacity and align domestic legislation with European and international standards (substantive legality), reforms do not improve and in fact lead to a deterioration of judicial impartiality and formal legality, thus undermining the development of the rule of law. This pathological impact is attributed to the EU's naive approach to reform, which is based on the partisan support of unaccountable reformers (which raises a reform ownership dilemma) and on the appreciation of quantity and speed of reforms (which raises a change vs. stability dilemma).

The next section briefly introduces my four-dimensional concept of the rule of law and provides quantitative evidence on the trends in rule of law development in CEE over the last 15 years. Section 3 then provides two explanations (dilemmas) accounting for lack of improvement in the rule of law despite considerable reform efforts. The paper concludes with some policy recommendations for the EU and for practitioners.

\footnotetext{
${ }^{1}$ CEE includes 22 countries: Albania, Armenia, Azerbaijan, Bosnia \& Herzegovina, Bulgaria, Croatia, Czech Republic, Estonia, Georgia, Hungary, Kosovo, Latvia, Lithuania, Macedonia, Moldova, Montenegro, Poland, Romania, Serbia, Slovakia, Slovenia, Ukraine.

${ }^{2}$ F Schimmelfennig, U Sedelmeier, The Europeanization of Central and Eastern Europe (Cornell University Press 2005); MA Vachudová, Europe undivided. Democracy, leverage, and integration after communism (Oxford University Press 2005); G Ekiert et al, 'Democracy in the Post-Communist World: An Unending Quest?' (2007) 21(1) East European Politics and Societies 7; $\mathrm{H}$ Grabbe, The EU's transformative power. Europeanization through conditionality in Central and Eastern Europe (Palgrave Macmillan 2006)

${ }^{3}$ Between 1997 and 2014, Freedom House's judicial framework and independence index decreased from 3.4 to 3.0 for CEE on an inverted scale where $1=$ worst and $7=$ best. Between 2004 and 2013, the Bertelsmann Stiftung's Transformation Index (BTI) rule of law index decreased slightly from 7.1 to 6.9 on a scale of 1 to 10 , where 1 is the worst and 10 the best.
} 


\section{Where does the EU's rule of law promotion fail?}

\section{A. The rule of law: a four-dimensional concept}

I propose a four-dimensional concept of the rule of law, consisting of four distinct dimensions: Formal legality, substantive legality, judicial capacity and judicial impartiality. ${ }^{4}$ While the two former dimensions refer to the quality of the formal rules (de jure rule of law), the two latter dimensions refer to the quality of the judicial system (de facto rule of law). The four key dimensions of the rule of law consist of sub-components, which allow measurement of the EU's impact on the rule of law in a more differentiated way.

First, the formal legality dimension includes the formal and procedural aspects of the rule of law (i.e. the "internal morality of $l a w^{\prime}$ ) which require laws to be general, publically promulgated, clear, non-retroactive, non-contradictory, possible to comply with, relatively stable, and enforced. ${ }^{5}$ My main focus will be on the stability of rules. Stability of laws implies that laws remain stable or unchanged for a period of time long enough to provide the necessary predictability and constraints of decision makers.

Second, substantive legality reflects a thick and substantive concept of the rule of law ${ }^{6}$ and requires the presence of morally "good" laws which comply with certain principles (e.g. justice, equality before the law) and certain rights (civil, political and socio-economic human rights). ${ }^{7}$ These principles and rights are commonly associated with international human rights norms and best-practices of governance (e.g. UN basic principles on the independence of the judiciary). International organisations, including the EU, promote the alignment with international human rights standards and best-practices and, in so doing, try to legally embed countries in the universal rules of the European or international legal system. ${ }^{8}$

Third, judicial capacity includes the inputs, means and resources to establish a capable judicial system. ${ }^{9}$ It is associated with the ability of a professional judiciary to enforce legislation in an efficient, timely and effective way. In particular, judicial capacity reflects the quantity and quality of the financial, technical and human resources required to establish a capable judicial system. However, higher judicial capacity does not automatically imply a better rule of law: resources (e.g. new computers, more prosecutors) can be misused to advance particularistic interests, such as political power, for instance in a politicised fight against corruption.

Fourth, judicial impartiality refers to the unbiased and impersonal enforcement of the law by independent, non-corrupt and accountable magistrates. The sub-components belonging to the

\footnotetext{
${ }^{4}$ M Mendelski, 'The Limits of the European Union's Transformative Power: Pathologies of Europeanization and Rule of Law Reform in Central and Eastern Europe' (Doctoral thesis, University of Luxembourg 2014); M Mendelski, 'The EU's pathological power: The failure of external rule of law promotion in South Eastern Europe' (2015) 39(3) Southeastern Europe 318

${ }^{5}$ LL Fuller, The morality of law (Yale University Press 1969) 46ff

${ }^{6}$ HLA Hart, The concept of law (Oxford University Press 1961)

${ }^{7}$ BZ Tamanaha, On the rule of law. History, politics, theory (Cambridge University Press 2004)

${ }^{8}$ BA Simmons, Mobilizing for human rights. International law in domestic politics (Cambridge University Press 2009)

9 M Mendelski, 'EU-driven judicial reforms in Romania: a success story?' (2012) 28(1) East European Politics 23; M Mendelski, 'The Limits of the European Union's Transformative Power: Pathologies of Europeanization and Rule of Law Reform in Central and Eastern Europe' (Doctoral thesis, University of Luxembourg 2014)
} 
judicial impartiality dimension include: 1. Judicial independence, 2. Separation of powers, 3. Judicial corruption, 4. Accountability towards the law, including the more specific concept of horizontal and vertical accountability and "government bound by law", 5. Judicial accountability and 6. Citizens' trust in the justice system, which can be regarded as an indicator of its procedural fairness, impartiality and competence. ${ }^{10}$

Finally, all four dimensions of the rule of law are interdependent. In order to create the rule of law, international donors must seek to improve all four dimensions in a balanced way. Achieving progress in one dimension and regressing in others does not necessarily enhance the rule of law. For instance, aligning domestic legislation with international standards will not establish the rule of law if the new laws and regulations become unstable, incoherent or are not enforced. Similarly, creating capable but not sufficiently impartial judiciaries (and vice versa) will not necessarily improve the rule of law. The next section shows that the EU (together with its domestic change agents) had precisely such an uneven effect on the four dimensions of the rule of law during the EU pre-accession period: ${ }^{11}$ while substantive legality and judicial capacity improved, formal legality and judicial impartiality stagnated and in part even deteriorated.

B. The EU aligns domestic laws with international standards (substantive legality), but undermines legal stability (formal legality)

Has the EU improved the de jure rule of law, i.e. the quality of the law? Figures 1 and 2 exhibit a potentially uneven (i.e. both positive and negative) impact of EU-driven reforms on the rule of law. While substantive legality increased in CEE, formal legality, and in particular the stability of laws, deteriorated. The two indicators, together with the literature and interviews with national representatives from the CEE, suggest that from 1998/2000 onwards, the EU was predominantly responsible for, 1. an intensified alignment of domestic legislation with European and international standards (including the approximation with the acquis communautaire) and, 2. an increased legislative output (i.e. the number of adopted laws) which, on average, more than doubled, and potentially deteriorated legal stability. In particular, speedy reforms, ushered in to meet demands of the EU (and other international donors), combined with the use of accelerated (i.e. fast-track) legislative procedures, had a detrimental impact on the legislative process in accession countries. $^{12}$

Romania is a telling example because EU pressure to ramp up judicial and anti-corruption reform, together with the accompanying political struggles resulted in numerous amendments of the law on the Judiciary. For instance, Law no. 92/1992 on the Organization of the Judiciary

\footnotetext{
$10 \mathrm{~J}$ Jackson et al. 'Trust in Justice: Topline Results from the Round 5 of the European Social Survey' 2011 European Social Survey (2011). "Trust in Justice: Topline findings from the European Social Survey", ESS Topline Results Series Issue $1 \mathrm{http}: / /$ ssrn.com/abstract=2231094.

11 The EU conditionality began to stimulate legal and judicial changes in Central Europe and the Baltics (CEB), Romania and Bulgaria since 1995/1998 and in most other states from South Eastern Europe (SEE) and the European Neighbourhood Policy (ENP) since 2004.

12 W Sadurski, 'Accession's Democracy Dividend: The Impact of the EU Enlargement upon Democracy in the New Member States of Central and Eastern Europe' (2004) 10(4) European Law Journal 371; F Millard, 'ExecutiveLegislative Relations in Poland, 1991-2005: Institutional Relations in Transition' (2008) 14(4) The Journal of Legislative Studies 367; T Bates, Assessment of the Legislative Process in the Republic of Moldova, (2010) Legis Paper-Nr. 167/2010 (LH/YA); N Ljubović, 'Role of Business Community in Legislative Procedure In Serbia' in N Jovanović (ed.), The Challenges of European Integration. Journal of Law and Economics of the European Integration (The Public Enterprise Official Gazette 2012) 77
} 
was modified 21 times between 1997 and 2005. Law no. 304/2004 on the judicial organization was amended 26 times between 2004 and 2013. Other frequently amended laws concerned the competencies of the Superior Council of Magistracy and relevant prosecutorial and administrative structures (e.g. DNA, DIICOT and ANI legislation). This legislative instability has reflected the more general trend of a considerable increase in emergency ordinances, legislative acts and laws during the pre-accession period to the EU. Data from the Romanian Chamber of Deputies indicates an escalating trend from 139 adopted laws in 1996, over 782 in 2001, towards 517 adopted laws in 2006). ${ }^{13}$

The overall uneven development in terms of formal legality (which deteriorated) and substantive legality (which improved) reflects the mixed impact of the EU and a common dilemma for reformers: how to improve the substantive quality of (the rule of) law whilst not undermining its formal, procedural quality, i.e. its "inner morality" (e.g. the legal stability and coherence). ${ }^{14}$ I will try to solve this dilemma in section 3 .

Figure 1: Development of substantive legality (rule approximation) in CEE

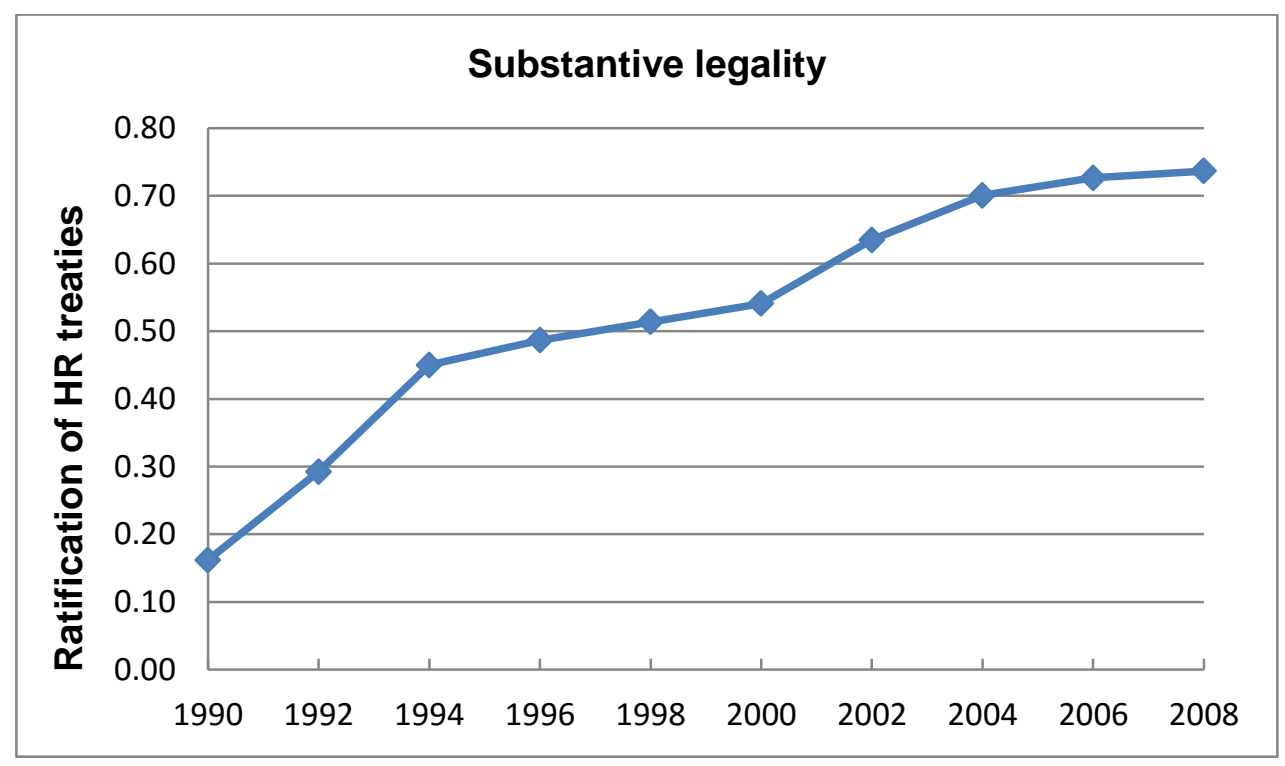

Source: Data based on Simmons 2009, provided to the author by Beth Simmons.

Notes: The indicator is based on the concept of "legal embeddedness" which calculates the proportion of 20 of the more important human rights related treaties ratified by each state. It includes additionally three regional agreements (Europe, Americas, and Africa). The scale ranges from 0 (worst performance) to 1 (best performance).

\footnotetext{
${ }^{13}$ See http://www.cdep.ro

${ }^{14}$ LL Fuller, The morality of law (New Haven, London: Yale University Press 1969)
} 
Figure 2: Development of formal legality (legislative output) in CEE

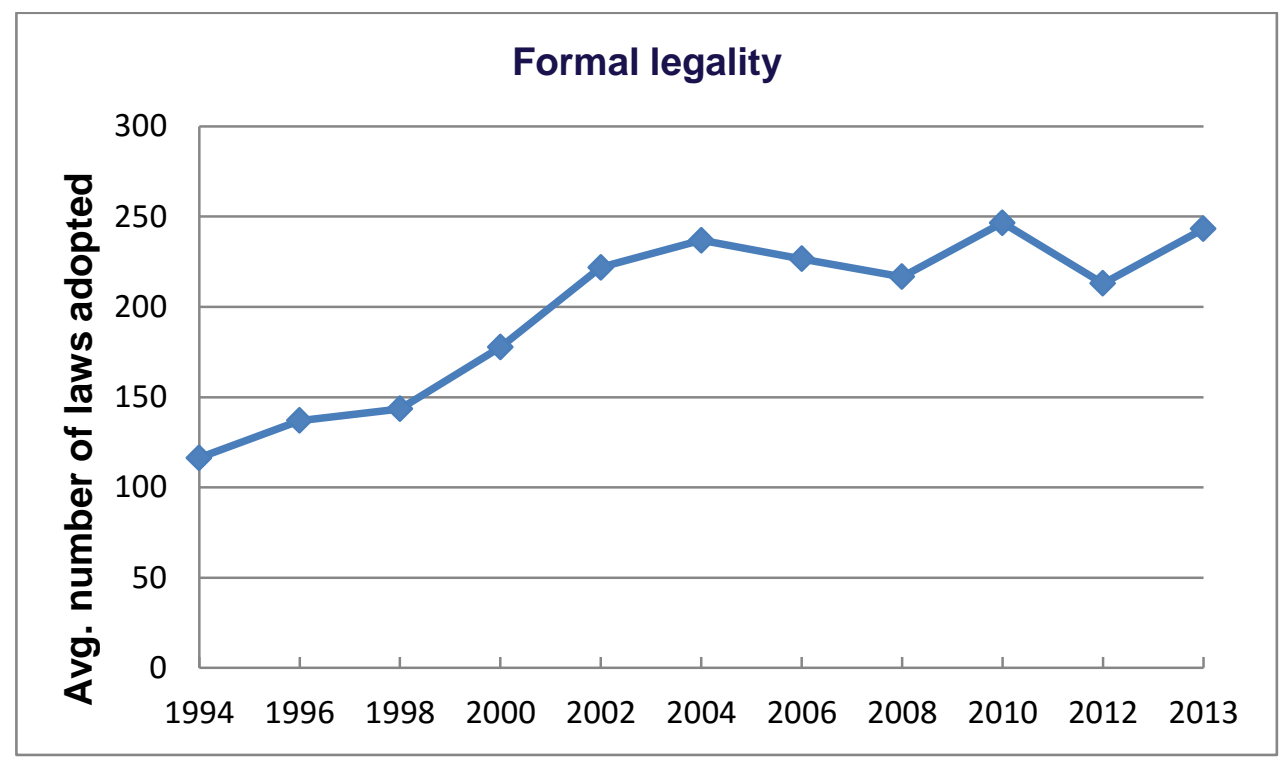

Source: Own dataset compiled by the author.

Notes: The data is based on the information from the national parliaments of 22 post-communist countries. The legislative output in CEE is measured as the simple average of nationally adopted laws per year.

\section{The EU strengthens judicial capacity but undermines judicial impartiality}

Has the EU improved the de facto rule of law in CEE, i.e. the quality of the judicial system? The answer seems to be yes with regard to judicial capacity, which improved considerably across all countries from CEE (see Figure 3). Surely, alternative explanations added to this positive trend, such as international donor conditionality, which focused on judicial capacity building as well as beneficial domestic economic conditions until 2008 (interrupted only briefly by the international financial crisis). In contrast to this positive trend, judicial impartiality experienced a stagnating, even deteriorating development, except for the slightly positive trend in judicial independence which remains in the median range (see Table 1). This suggests that the EU and domestic reformers were unable to establish accountable, independent, non-corrupt and trusted judiciaries. The lack of progress indicated by the data in Table 1 suggests that improving certain crucial values (judicial independence, accountability, respect of law, fair trial etc.) is a pathdependent and complex process, which is difficult to change in the short-term. In sum, the EU's impact was potentially uneven across the four key dimensions of the rule of law: while substantive legality and judicial capacity improved, formal legality and judicial impartiality did not. 
Figure 3: Development of judicial capacity in CEE

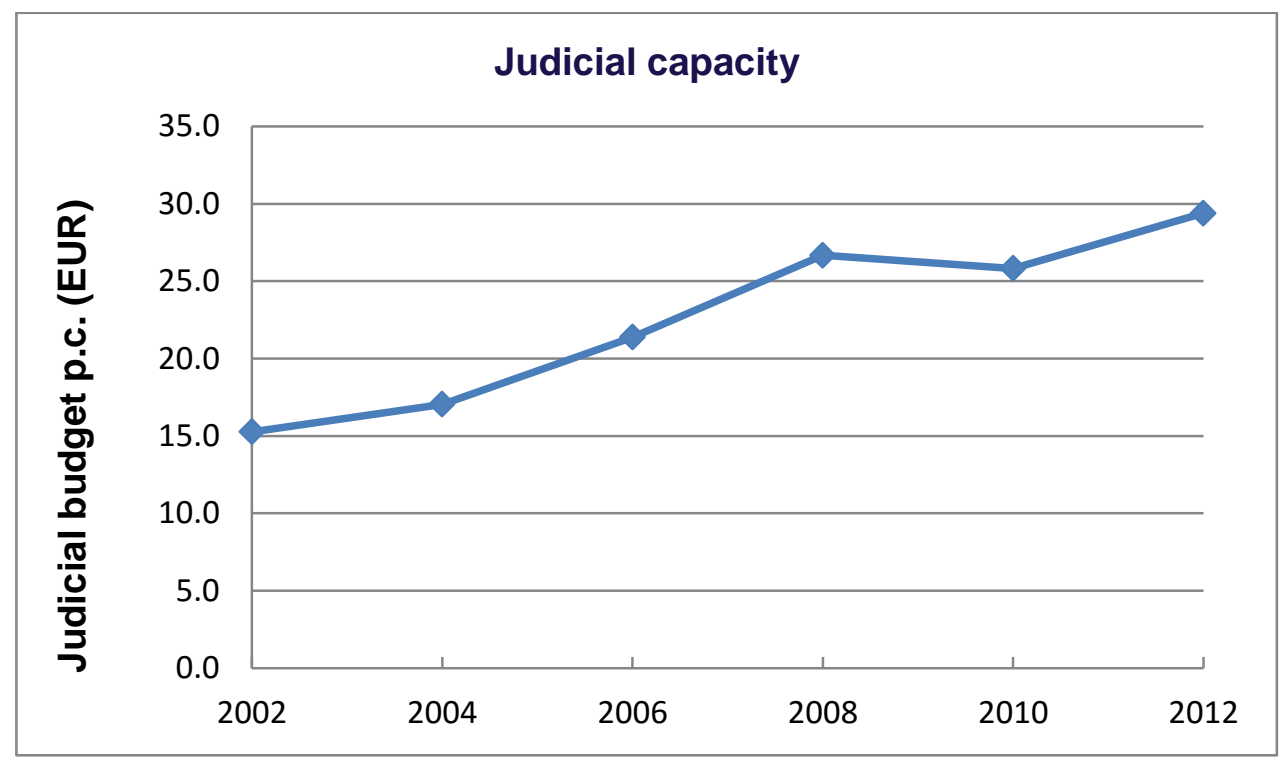

Source: Own calculations based on data from CEPEJ 2004; 2006; 2008; 2010; 2012; 2014 http://www.coe.int/t/dghl/cooperation/cepej/evaluation/

Table 1: Development of judicial impartiality in CEE

\begin{tabular}{|l|c|c|c|c|c|c|c|c|}
\hline & 2002 & 2004 & 2006 & 2008 & 2010 & 2012 & $\begin{array}{c}\text { absolute } \\
\text { change } \\
\text { (2002- } \\
\text { 2012) }\end{array}$ & $\begin{array}{c}\text { relative } \\
\text { change } \\
\text { in \% } \\
\text { (2002- } \\
\text { 2012) }\end{array}$ \\
\hline $\begin{array}{l}\text { Judicial Independence, } \\
\text { WEFEOS, scale from 1-7 }\end{array}$ & 3.0 & 2.9 & 3.1 & 3.3 & 3.2 & 3.2 & +0.16 & +5.1 \\
\hline $\begin{array}{l}\text { Corruption in the legal } \\
\text { system/judiciary, TI, scale 1-5 }\end{array}$ & $\mathrm{n} / \mathrm{a}$ & 2.2 & 2.0 & 2.1 & 2.3 & 2.2 & 0 & 0 \\
\hline $\begin{array}{l}\text { Irregular payments in judicial } \\
\text { decision, WEFEOS, scale from 1-7 }\end{array}$ & 4.1 & 4.3 & 3.8 & 3.6 & 3.6 & 3.6 & -0.52 & -12.7 \\
\hline $\begin{array}{l}\text { Separation of powers, } \\
\text { BTI, Scale 1-10 }\end{array}$ & $\mathrm{n} / \mathrm{a}$ & 7.4 & 7.7 & 7.5 & 7.3 & 7.0 & -0.37 & -5.0 \\
\hline $\begin{array}{l}\text { Prosecution of office abuse } \\
\text { (accountability), BTI, Scale 1-10 }\end{array}$ & $\mathrm{n} / \mathrm{a}$ & 6.5 & 6.6 & 6.3 & 6.3 & 6.4 & -0.04 & -0.6 \\
\hline $\begin{array}{l}\text { Citizens' trust into justice/courts, } \\
\text { EB (\%) }\end{array}$ & 31.3 & 29.8 & 31.5 & 28.9 & 31.0 & $\mathrm{n} / \mathrm{a}$ & -0.3 & -0.3 \\
\hline
\end{tabular}

Sources: World Economic Forum's Executive Opinion Survey (WEFEOS); Freedom House (FH); Bertelsmann

Transformation Index (BTI); Transparency international (TI); Eurobarometer (EB).

Note: Original TI scale was inverted, so that higher values reflect better performance. 


\section{Why does the EU's rule of law promotion fail and what can be done about it?}

In this section, I identify two key dilemmas for the EU and domestic reformers, which reflect the inadequate reform approach of transnational reform coalitions between domestic change agents and the EU. In addition, I suggest policy recommendations to solve these dilemmas.

\section{A. Dilemma of ownership of rule of law reform: The problem of supporting unaccountable reformers in a partisan way}

The first dilemma reflects the EU's selective and inconsistent application of EU conditionality, ${ }^{15}$ including the empowering and support of reformist change agents, no matter how undemocratically they behave. Giving reform ownership to domestic elites with vested interests (such as pro-European oligarchs in Moldova and Ukraine, pro-Western authoritarian leaders in Caucasus countries, or simply reformist politicians from the old (or new) guard in Romania, Serbia and Kosovo) can be highly problematic for establishing the rule of law. Change agents in weak rule of law countries often lack the appropriate incentives, norms and skills to conduct reforms in a non-politicised, inclusive and long-term oriented way. Many of the EU's reformist change agents from post-Soviet states and the Western Balkans, instead of respecting the rule of law, (mis)use the law and the judicial system as a weapon against their political and economic competitors, who, once in power, behave in a similar way. ${ }^{16}$ The results of these domestic power struggles are vicious cycles of reform and counter-reform with detrimental effects for the rule of law and in particular for legal stability, judicial independence and accountability. ${ }^{17}$ In short, empowering questionable and unaccountable pro-EU elites in countries with weak rule of law and giving them a free hand in conducting reforms without the necessary restrictions creates new possibilities of abusing reforms and undermining the rule of law. Reforms do not automatically mean progress, especially under unfavourable conditions with insufficient institutional or democratic checks to control reformers. ${ }^{18}$

But what can be done about it? How can this dilemma be solved? First, the EU needs to become more consistent and non-partisan in its evaluation of governments. In particular, it should not grant "honeymoon periods" to pro-Western change agents after regimes changes (e.g. as in Moldova, Ukraine, or Georgia), particularly when they break or misuse the law, disrespect

\footnotetext{
${ }^{15}$ F Schimmelfennig, 'Europeanization beyond Europe' (2015) 10(1) Living Reviews in European Governance, see www.europeangovernance-livingreviews.org; TA Börzel, V Van Hüllen, 'One voice, one message, but conflicting goals: cohesiveness and consistency in the European Neighbourhood Policy' (2014) 21 (7) Journal of European Public Policy 1033

${ }^{16} \mathrm{M}$ Mendelski, 'Rule of Law Reforms in the Shadow of Clientelism: The Limits of the EU's Transformative Power in Romania'. Polish Sociological Review (2011) 2 (174) 235; M. Mendelski 'They Have Failed Again! Donor-driven Promotion of the Rule of Law in Serbia' (2013) 61(1) Südost-Europa : Zeitschrift für Politik und Gesellschaft 79; TA Börzel and Y Pamuk, 'Pathologies of Europeanisation: Fighting Corruption in the Southern Caucasus' (2011) 35(1) West European Politics 79; $M$ Natorski "Reforms in the judiciary of Ukraine: domestic practices and the EU's policy instruments" (2013) 29(3) East European Politics 358. M Popova Politicized justice in emerging democracies: a study of courts in Russia and Ukraine. (Cambridge University Press 2012)

${ }_{17}$ M Mendelski, 'The EU's pathological power: The failure of external rule of law promotion in South Eastern Europe' (2015) 39(3) Southeastern Europe 318

${ }^{18}$ M Mendelski, 'The Limits of the European Union's Transformative Power: Pathologies of Europeanization and Rule of Law Reform in Central and Eastern Europe' (Doctoral thesis, University of Luxembourg 2014)
} 
human rights, engage in corruption or instrumentalise anti-corruption and judicial reforms. ${ }^{19}$ Rather than focusing on regime change and a few selected liberal change agents, the EU should reward elites who apply an impartial, depoliticised and inclusive reform approach, foster domestic consensus and regard the law as a necessary constraint rather than a tool. However, working with more law-abiding, professional and independent reformers is not sufficient. The EU should also pay more attention to the quality of the reform process and, in particular, to the avoidance of legal reform pathologies, such as legal instability, which I address in the next section.

\section{B. Dilemma of change vs. stability: The problem of valuing quantity over quality}

The change vs. stability dilemma essentially refers to the opportunities for and challenges of improving the substantive quality of the law whilst not undermining its inner morality (i.e. its stability, coherence and enforcement). This dilemma is especially pertinent in weak rule of law countries from South Eastern Europe (SEE) and post-Soviet countries, which suffer much more from legal instability, incoherence and lack of enforcement than more advanced countries from Central Europe and the Baltics (CEB). The experience with judicial reforms in CEE shows that the differences in legal pathologies result often from differences in the reform process. While the laggard countries from SEE and the ENP-region try to catch-up and conduct radical, ad-hoc and speedy reforms in order to meet EU conditionality criteria, the front-runner countries from CEB seem to reform in a more gradual and adaptive way, paying more attention to legal coherence, stability and judicial independence. ${ }^{20}$

In part, this is because reformers in advanced countries are beneficially constrained by "vertical accountability" (i.e. elections and civic groups) and/or independent "horizontal accountability" institutions (e.g. Constitutional Courts, Ombudsmen, regulatory agencies), which results in less abuse of judicial reforms. ${ }^{21}$ By contrast, such horizontal beneficial constraints of the executive are weak and politicised in laggard countries. This leads reformers to conduct radical and unaccountable reforms by means of emergency ordinances, fast-track procedures or presidential decrees, which altogether speeds up the reform process but makes it more pathological and less democratic. This speedy reform process also limits the creation of a deliberative democracy ${ }^{22}$, which would improve legislative decision making through debate, consensus and critical feedback. The overall result of such hasty, top-down and unconstrained reforms is coercive and mimetic adaptation to best standards (e.g. introduction of judicial councils, anti-corruption agencies), followed by resistance, counter-reforms, decoupling (lack of implementation), as well as legal and political instability.

\footnotetext{
19 T A Börzel, Y Pamuk, 'Pathologies of Europeanisation: Fighting Corruption in the Southern Caucasus' (2011) 35(1) West European Politics 79; M Mendelski, 'The EU's Pathological Power: The Failure of External Rule of Law Promotion in South Eastern Europe' (2015) 39(3) Southeastern Europe 318

${ }^{20}$ This should be understood in terms of degrees. Note that also reforms in the Czech Republic, Poland, and recently also in Hungary resulted in a strong increase of legislative output. This suggests that even former frontrunners are not immune to reform pathologies which affect the inner morality of law.

${ }^{21}$ Mendelski, M. (The Limits of the European Union's Transformative Power: Pathologies of Europeanization and Rule of Law Reform in Central and Eastern Europe (Doctoral thesis University of Luxembourg 2014)

22 J Elster Deliberative democracy (Cambridge University Press 1998)
} 
Unfortunately, the EU reinforces these legal pathologies by placing emphasis on speedy reforms which stress quantitative outcomes (more laws, more resources, more convictions, more arrests etc.) over the qualitative reform processes and procedures (i.e. how laws, arrests or convictions are made). An illustrative example from the Western Balkans might suffice here to elucidate the EU's quantitative approach to reform. A typical Twinning Project evaluation fiche on organised crime and corruption in this region mentions the following quantitative indicators to measure progress: number of serious crime cases dealt with, number of witnesses coming forward, number of meetings, exchange programmes and participants, number of documents produced, number of technical arrangements, number of legislative standards, number of rules of procedure and guidelines drafted and adopted, number of judges and prosecutors trained, number of national key and secondary legislation drafted and adopted, number of legislation and cooperation agreements in place, ratio of information on best practice successfully exchanged and applied, number of training courses provided, number of working groups established.

However, by relying on this kind of 'more is better' mindset, the EU (together with other international donors) has produced and reinforced reform pathologies which have undermined the rule of law in many CEE countries. The demand for more laws fostered legal inflation and instability. The demand for more judicial independence resulted in more independent but unaccountable judicial councils. Similarly, the demand for a "solid track record" in fighting highlevel corruption cases has led to increasing the number of convictions, but also to an increased misuse of anti-corruption legislation and newly established agencies. ${ }^{23}$

Rule of law reforms can be abused and can reinforce legal pathologies. Under these circumstances, the post-accession dismantling of newly created or empowered (but dysfunctional) horizontal accountability structures such as Judicial Councils, Constitutional Courts and anticorruption agencies - are not "deliberate rule of law crises", but rather domestic counterreactions to hasty, quantity-driven, politicised and non-inclusive reforms. Thus, reform-resistance and backslash is not necessarily something harmful (as depicted by reformist politicians and the European Commission), but can be seen as a mechanism to correct legal pathologies or dysfunctional oversight and horizontal accountability institutions.

\section{Policy implications: "It's the reform process, stupid!"}

EU conditionality should be re-focused from quantitative outcomes towards qualitative processes. In particular, the EU should not link conditionality to specific reform outcomes or benchmarks (e.g. bringing war criminals before the court, increasing the number of high-level corruption cases or adoption of certain laws or first-best practices, which often turn into dysfunctional legal transplants). Rather, the EU should link conditionality to the reform process itself which underlies

\footnotetext{
${ }^{23}$ Trimble, M. Legal Landscape in a 'Legislative Hurricane': Impact of the 2004 European Union Enlargement on Czech Legislative Process 2010 Available at SSRN: http://ssrn.com/abstract=908043; R Coman, 'Quo Vadis Judicial Reforms? The Quest for Judicial Independence in Central and Eastern Europe' (2014) 66(6) Europe-Asia Studies 892; AL Capussela State-Building in Kosovo: Democracy, Corruption and the EU in the Balkans (IB Tauris 2015). M Bobek, D Kosar "Global Solutions, Local Damages: A Critical Study in Judicial Councils in Central and Eastern Europe" (2014) 15(2) German Law Journal 1257; M Mendelski, 'The EU's pathological power: The failure of external rule of law promotion in South Eastern Europe' (2015) 39(3) Southeastern Europe 318; L Di Puppo, L. 'Anti-corruption interventions in Georgia' (2010) 11 (2) Global Crime 220.
} 
these outcomes (including the use of process-related indicators). This more qualitative approach should pay attention to formal legality (the "inner morality" of law) and take a holistic and systemic approach, which focuses on all 4 key dimensions of the rule of law. Otherwise, the selective progress in some dimensions of the rule of law (formal legality and judicial capacity) may be undermined by the deterioration in the other dimensions (formal legality and judicial impartiality).

The main message for practitioners and the EU is that how reforms are conducted matters. Successful judicial and legal reforms should be evaluated in a non-partisan way and focus more on quality rather than on quantity and speed. Legal quality should not simply be assessed by the number of laws aligned with best practices and international standards, but by the inner quality of laws (i.e. clear, stable, coherent and enforced rules). Similarly, judicial quality should not simply be assessed in terms of the number of human and financial resources or efficiency indicators, (as is currently done by CEPEJ or the EU Justice Scoreboard) but pay much more attention to the impartiality and accountability of the reform process itself.

The implications of this for the EU are clear: the EU needs to improve the currently flawed and inconsistent methodology of rule of law evaluation, which opens the doors to bias and double standards. ${ }^{24}$ An enhanced approach requires the naive methodology of measuring the rule of law in a quantitative and additive way to be abandoned, employing, instead, a more objective, qualitative and multiplicative methodology, which pays attention to a balancing of rule of law dimensions (and components), reform processes and the diverse domestic conditions under which reforms are conducted.

\footnotetext{
${ }^{24} \mathrm{D}$ Kochenov, EU enlargement and the failure of conditionality. Pre-accession conditionality in the fields of democracy and the rule of law (Wolters Kluwer 2008); G Dimitrov, et al, The Cooperation and Verification Mechanism: Shared Political Irresponsibility between the European Commission and the Bulgarian Governments (St. Kliment Ohridski University Press 2014); L Toneva-Metodieva, 'Beyond the Carrots and Sticks Paradigm: Rethinking the Cooperation and Verification Mechanism Experience of Bulgaria and Romania' (2014) 15(4) Perspectives on European Politics and Society 534; M Mendelski, 'The EU's pathological power: The failure of external rule of law promotion in South Eastern Europe' (2015) 39(3) Southeastern Europe 318
} 


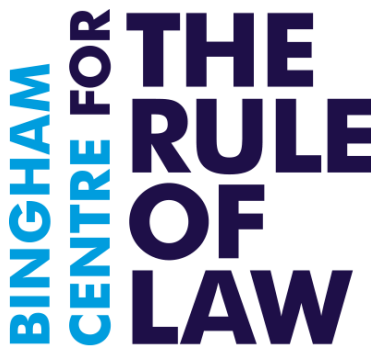

\section{The Global Rule of Law Exchange}

The Global Rule of Law Exchange ('the Exchange') is a project of the Bingham Centre for the Rule of Law in London supported by law firm Jones Day. The Exchange aims to address key challenges posed by global development and its relationship to the rule of law. It will consider the place of the rule of law in emerging economies, including on issues such as access to justice, administrative justice and corruption. It will also examine the relationship between formal and informal legal systems and the measurement of success in rule of law interventions (See: http://ruleoflawexchange.org/)

\section{The Bingham Centre for the Rule of Law}

Bingham Centre for the Rule of Law

Charles Clore House

17 Russell Square

London WC1B 5JP

Tel: $+44(0) 2078625154$

Email: binghamcentre@biicl.org

Web: www.binghamcentre.biicl.org

The Bingham Centre for the Rule of Law was launched in December 2010 to honour the work and career of Lord Bingham of Cornhill - a great judge and passionate advocate of the rule of law. The Centre is dedicated to the study, promotion and enhancement of the rule of law worldwide. It does this by defining the rule of law as a universal and practical concept, highlighting threats to the rule of law, conducting high quality research and training, and providing rule of law capacity-building to enhance economic development, political stability and human dignity: www.binghamcentre.biicl.org

The Bingham Centre is a constituent part of the British Institute of International and Comparative Law (BIICL), a registered charity and leading independent research organisation founded over 50 years ago: www.biicl.org

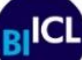

British Institute of International and
Comparative Lav

\section{About this document}

Citation: This document should be cited as: M Mendelski, 'The EU's Rule of Law Promotion in Central and Eastern Europe: Where and Why Does it Fail, and What Can be Done About It?' Global Rule of Law Exchange Practice Notes, Bingham Centre for the Rule of Law, London, 2016.

Copyright: (C) The author and Bingham Centre for the Rule of Law / BIICL. This document is available for free download from the Bingham Centre's web site. It should not be reproduced without the Bingham Centre's express written permission.

Acknowledgment: The Global Rule of Law Exchange is funded by law firm Jones Day. 